\title{
Oppenheimer case boils up again
}

Files show FBI bugged pre-trial conversations

\section{Washington}

A forthcoming history of science journal reveals new information on the celebrated Oppenheimer case - the most traumatic incident in post-war US science - that suggests that the government stacked the case against Oppenheimer in proceedings that caused the revocation of his security clearance and his personal disgrace.

Physicist J. Robert Oppenheimer led the Los Alamos atomic bomb project during the Second World War. Afterwards, he was the unquestioned leader among US physicists seeking to shape the post-war world. Oppenheimer was influential in the debate over civilian control of atomic energy and, later, chairman of the General Advisery Committee of the Atomic Energy Commission (AEC). Oppenheimer was then without doubt the government's most influential science adviser.

But doubts about his possible pre-war Communist associations, and his apparent evasions in relation to them, led AEC to conduct an inquiry into his suitability to hold security clearance, and to a hearing before a specially appointed triumverate of AEC's Personnel Security Board in 1954. The hearing, including the testimony of his one time colleague Edward Teller, destroyed him.

An article by Barton J. Bernstein, Professor of History at Stanford University, in Historical Studies in the Physical Sciences*, to be published later this spring, alleges that despite President Eisenhower's stated wish that the government should conduct the inquiry in a dignified manner, commensurate with Oppenheimer's stature, the Federal Bureau of Investigation (FBI) nonetheless bugged Oppenheimer's conversations with his attornies before the inquiry and passed the transcripts on to prosecutor Roger Robb. AEC chairman Lewis Strauss personally thanked the FBI for their help in supplying the transcripts. "It would be an uneven contest", even before the hearing, writes Bernstein, "just as if one army had stolen its enemy's secret plans".

Moreover, Bernstein says, while members of the board and the prosecution had access to secret FBI files on Oppenheimer (some of which were unopened at the time that the government had given Oppenheimer earlier security clearances), these were never shown to

*Historical Studies in the Physical Sciences, Office for the History of Science and Technology, 470 Stevens Hall, University of California, Berkeley, California 94720 , USA.

Oppenheimer or his attornies on the grounds that security clearance could not be obtained in time.

These and other revelations are based on documents declassified by the FBI, the Department of Energy (successor to AEC) and the Eisenhower Library at Bernstein's request. But Bernstein believes there is still more to learn about the case, as "more than half" of the FBI material on Oppenheimer remains classified.

The chairman of the three-member panel that finally judged Oppenheimer a security risk was Gordon Gray, former president of the University of North Carolina and former Secretary of the Army. Gray's papers, unearthed by Bernstein, show that Gray considered the other two members of the board to be completely prejudiced against Oppenheimer before the hearing even started. The three sat down together beforehand, to go through the files. Gray wrote of the other two, "It seemed to me from the beginning that Mr Morgan and Dr Evans both had a strong hunch that $\mathrm{Dr}$ Oppenheimer's clearance should not be reinstated ... During the weeks spent reading through the files this notion became much clearer." Evans made antiSemitic comments, saying that he found "that nearly all subversives were Jews". "At the time I was concerned at this note of clear prejudice", Gray wrote. But he did not tell AEC that the board's members were not impartial as AEC rules required.

Bernstein's new documents also reveal that Edward Teller, whose testimony was crucial, had told the FBI some years earlier of his doubts about Oppenheimer, and that Teller's statements helped shape the charges. Teller, however, has said that he was undecided about Oppenheimer until

\section{Merck backs UK neuroscience}

Dr Leslie Iversen, director of the Medical Research Council's neurochemical pharmacology unit at Cambridge for the past eleven years, has been appointed director of a new laboratory being established in Britain by Merck, Sharp and Dohme. The new laboratory, which will be a going concern on a greenfield site near Harlow, Essex, by 1984, will be exclusively concerned with basic drugoriented research in the neurosciences and will eventually employ 200 people, a third of them with research degrees.

The British scientific community is delighted at this development, chiefly because of the jobs it will provide for researchers but also because it is a token of continuing American interest in the United Kingdom as a base for major research laboratories.

Dr Iversen said earlier this week that he was looking forward to the job, but emphasized that while the new research the night before he testified, when Robb showed him Oppenheimer's security record.

But in 1952, according to Bernstein's article, Teller told the FBI that he would do almost anything to separate Oppenheimer from the General Advisery Committee because Oppenheimer had cleverly shifted from one argument to another on the committee and used his considerable influence over other scientists to delay development of the hydrogen bomb. In 1952, Teller had not said that Oppenheimer was disloyal, only that he was dangerous because he gave bad advice. To Teller in 1952, Bernstein writes Oppenheimer "was devious but not disloyal". He had persuaded Hans Bethe to refuse to work on the H-bomb and had swayed Henry D. Smyth, an AEC commissioner, to oppose it.

Bernstein believes that his new information also provides an even more "alloyed" portrait of Oppenheimer himself than has emerged in previous writing about the case, which has tended to portray Oppenheimer as a martyr. The documents show, Bernstein writes, evidence of "a string of lies and evasions" regarding his past, and that Oppenheimer had not always been candid with the authorities or his associates. Commenting on the strain that Oppenheimer visibly underwent at the hearing, Bernstein writes:

Oppenheimer was struggling to preserve his reputation .... He lost. And he may have been under an additional strain that his defenders did not appreciate, for he may also have been hiding his former membership in the Communist party. Chevalier claimed that Oppenheimer had been a member, and Robb reached the same conclusion.

However, except for wondering what is in the yet unopened files, Bernstein says there

centre would concentrate largely on basic neuroscience, it would be an integral part of the company's research effort and thus different from the Roche research centres in Switzerland and the United States. The hope, he said, was that basic neuroscience research would suggest novel classes of therapeutic drugs.

The only cloud on the horizon is the future of the Medical Research Council's unit, which is to be decided in June this year and which has been for some years one of the brightest feathers in the council's cap. Dr Iversen says that he is anxious that the unit should survive his departure on 1 March next year, for which reason he intends to avoid recruiting any of his present staff until the council has made up its mind. Apart from the unit's basic research, it also houses the United Kingdom "brain bank" from which authenticated samples of brain tissue are distributed to qualified investigators. 